\title{
THE
}

\section{Facilitation between invasive herbivores: hemlock woolly adelgid increases gypsy moth preference for and performance on eastern hemlock}

Ian G. Kinahan

University of Rhode Island

Alex K. Baranowski

University of Rhode Island

Elizabeth R. Whitney

University of Rhode Island

SulfaphêKis Sandagagitional works at: https://digitalcommons.uri.edu/bio_facpubs lniunraitu of Dhnda Inland

The University of Rhode Island Faculty have made this article openly available.

Please let us know how Open Access to this research benefits you.

This is a pre-publication author manuscript of the final, published article.

Terms of Use

See next page for additional authors

This article is made available under the terms and conditions applicable towards Open Access

Policy Articles, as set forth in our Terms of Use.

\section{Citation/Publisher Attribution}

Kinahan, I.G., Baranowski, A.K., Whitney, E.R., Savage, S.K., Rigsby, C.M., Shoemaker, E.E., Orians, C.M. and Preisser, E.L. (2020), Facilitation between invasive herbivores: hemlock woolly adelgid increases gypsy moth preference for and performance on eastern hemlock. Ecol Entomol, 45: 416-422. doi:10.1111/ een.12829

Available at: https://doi.org/10.1111/een.12829 


\section{Authors}

Ian G. Kinahan, Alex K. Baranowski, Elizabeth R. Whitney, Suzanne K. Savage, Chad M. Rigsby, Emma E. Shoemaker, Colin M. Orians, and Evan L. Preisser

This article is available at DigitalCommons@URI: https://digitalcommons.uri.edu/bio_facpubs/214 
1 Running title: Facilitation between invasive herbivores

3 Title: Facilitation between invasive herbivores: hemlock woolly adelgid increases gypsy moth

4 preference for and performance on eastern hemlock

6 Authors: Ian G. Kinahan ${ }^{1}$, Alex K. Baranowski ${ }^{1}$, Elizabeth R. Whitney ${ }^{1}$, Suzanne K. Savage ${ }^{1}$,

7 Chad M. Rigsby ${ }^{1,2}$, Emma E. Shoemaker ${ }^{1}$, Colin M. Orians ${ }^{3}$, Evan L. Preisser ${ }^{1,4}$

$9{ }^{1}$ Department of Biological Sciences, The University of Rhode Island, Kingston RI 02881 USA

$10 \quad{ }^{2}$ Current address: Bartlett Tree Research Laboratories, Charlotte, NC 28278 USA

$11 \quad{ }^{3}$ Department of Biology, Tufts University, Medford MA 02155 USA

$12 \quad{ }^{4}$ Author for correspondence

14 Correspondence: Evan Preisser, Department of Biological Sciences, The University of Rhode

15 Island, Kingston RI 02881 USA, telephone: 401 874-2120, email: preisser@uri.edu 
16 Abstract.

17 1. Interactions between invertebrate herbivores with different feeding modes are common on

18 long-lived woody plants. In cases where one herbivore facilitates the success of another, the

19 consequences for their shared host plant may be severe. Eastern hemlock (Tsuga canadensis), a

20 canopy-dominant conifer native to the eastern U.S., is currently threatened with extirpation by

21 the invasive stylet-feeding hemlock woolly adelgid (Adelges tsugae). The effect of adelgid on

22 invasive hemlock-feeding folivores remains unknown.

23 2. We evaluated the impact of feeding by hemlock woolly adelgid on gypsy moth (Lymantria

24 dispar) larval preference for, and performance on, eastern hemlock. To assess preference, we

25 surveyed 245 field-grown hemlocks for gypsy moth herbivory damage and conducted laboratory

26 paired-choice bioassays. To assess performance, gypsy moth larvae were reared to pupation on

27 adelgid-infested or uninfested hemlock foliage and pupal weight, proportional weight gain, and

28 larval period were analyzed.

29 3. Adelgid-infested hemlocks experienced more gypsy moth herbivory than uninfested control

30 trees, and laboratory tests confirmed that gypsy moth larvae preferentially feed on adelgid-

31 infested hemlock foliage. Gypsy moth larvae reared to pupation on adelgid-infested foliage

32 gained more weight than larvae reared on uninfested control foliage.

33 4. Our results suggest that the synergistic effect of adelgid and gypsy moth poses an additional

34 threat to eastern hemlock that may increase extirpation risk and ecological impact throughout

35 most of its range.

36

37 Key words. Facilitation, herbivores, Adelges tsugae, Lymantria dispar, invasional meltdown 


\section{Introduction}

Many interactions between co-occurring insect herbivores are mediated by their impact on the shared host plant (Kaplan \& Denno, 2007). Feeding by one insect may cause alterations in

41 plant quality, such as the induction of toxic secondary metabolites or changes to various leaf

42 structural traits, which can affect simultaneously- or sequentially-feeding competitors (Nykänen

$43 \&$ Koricheva, 2004). Although many such changes negatively impact the other species, they can

44 also be facilitative (Kaplan \& Denno, 2007; Ohgushi, 2008). Sap feeding by the aphid

45 Brevicoryne brassicae, for example, improves the performance of folivorous Pieris brassicae

46 larvae by attenuating chemical defense induction in Brassica oleracea (Li et al., 2014).

47 Understanding herbivore-herbivore interactions is especially important in cases where

48 one or both herbivores can substantially affect plant growth and fitness. One such species is

49 hemlock woolly adelgid (Adelges tsugae; 'adelgid' hereafter), a destructive pest that has caused

50 widespread mortality and decline of an ecologically significant conifer, eastern hemlock (Tsuga

51 canadensis; 'hemlock' hereafter), in eastern U.S. forests. Adelgid feeds by inserting its stylet

52 bundle into the xylem ray parenchyma cells at the base of a hemlock needle (Shields et al.,

53 1995). This feeding reduces the production of new foliage (Gonda-King et al., 2014; McClure,

54 1991), alters wood morphology (Domec et al., 2013; Gonda-King et al., 2012), and substantially

55 impacts plant physiology. Adelgid-infested hemlocks have elevated tissue levels of salicylic acid

56 (SA) and emissions of its methylated form, methyl salicylate (Pezet et al., 2013; Pezet \&

57 Elkinton, 2014). SA is a phytohormone that plays a critical role in plant response to abiotic

58 stresses and biotrophic pathogens; it has also been shown to accumulate following stylet-feeding

59 insect infestations (Walling, 2000). SA accumulation and subsequent monomerization of NPR1,

60 a transcriptional regulator that promotes the expression of SA-responsive genes, can interfere 
61 with the biosynthesis of jasmonic acid (JA)/ethylene-dependent defenses that help protect against

62 leaf-chewing herbivores (Walling, 2008; Zarate et al., 2007). Adelgid feeding has also been

63 shown to increase nitrogen (Gonda-King et al., 2014) and total amino acid content (Gomez et al.,

64 2012) in hemlock needles. Because nitrogen is critical to insect growth (Awmack \& Leather,

65 2002; Kerslake et al., 1998), such adelgid-mediated increases may enhance host plant quality for

66 folivorous herbivores.

67 Recent work in the hemlock system suggests that adelgid-induced phytochemical changes

68 may influence interactions between hemlock and other herbivores (Rigsby et al., 2019; Schaeffer

69 et al., 2018; Wilson et al., 2018). Larvae of the native hemlock looper (Lambdina fiscellaria) had

70 higher survival and enhanced larval development when reared on adelgid-infested versus

71 uninfested hemlock foliage (Wilson et al., 2016). This work led us to explore whether similar

72 interactions might be occurring between the adelgid and more commonly-occurring folivores.

73 We focused our attention on gypsy moth (Lymantria dispar), an invasive folivore that has

74 devastated eastern U.S. forests. Since its introduction in 1890, periodic gypsy moth outbreaks

75 have defoliated millions of acres and altered forest structure and composition (Gandhi \& Herms,

76 2010; Lovett et al., 2006). Gypsy moth can feed on eastern hemlock (Lovett et al., 2006) and

77 although it and hemlock woolly adelgid co-occur in their introduced range, their interactions

78 have not been considered.

79 We report the results of work assessing the impact of adelgid infestation on gypsy moth-

80 hemlock interactions. We surveyed hemlocks planted into a deciduous forest understory for

81 gypsy moth herbivory and conducted two laboratory experiments to measure gypsy moth

82 preference for, and performance on, adelgid-infested hemlock foliage. Because the adelgid

83 inhibits hemlock anti-folivore defense pathways and increases the nutritional value of its needles, 
84 we hypothesized that gypsy moth larvae would both prefer (consume more of) and do better

85 (pupate at higher weights) on adelgid-infested foliage. The 'invasional meltdown hypothesis'

86 suggests that much of the damage caused by introduced species may result from positive

87 interactions between invaders that can facilitate their establishment and increase their ecological

88 impact (Simberloff \& Von Holle, 1999). Our findings illustrate the potential for such facilitation

89 between two invasive herbivores and highlight the threat this may pose to their shared host and

90 its associated ecosystem.

$91 \quad$ Materials and Methods

$92 \quad$ Field preference survey: Our field preference survey took advantage of a 2016 gypsy

93 moth outbreak to assess their impacts on field-grown eastern hemlock. The trees in this survey

94 were planted in 2014 for use in an unrelated experiment. Briefly, 1-1.2 m-tall hemlock saplings

95 were purchased from Van Pines Nursery (West Olive, MI) in spring 2014, planted, and grown

96 for two years in the understory of a mixed hardwood stand at the Kingston Wildlife Research

97 Station (South Kingstown, RI). Hemlocks were planted in five 64-tree blocks, with each tree

98 spaced 1-1.5 $\mathrm{m}$ apart. Trees were protected from herbivory and cross-contamination of

99 treatments with chicken-wire cages covered by mesh bags (Agribon-15, Johnny's Selected

100 Seeds, Waterville, ME, USA; 90\% light transmission. Sixteen trees in each block were randomly

101 assigned one of the following two treatments: infestation with adelgid or another invasive

102 herbivore (Fiorinia externa; elongate hemlock scale, 'scale' hereafter). The remaining 32 trees in

103 each block were maintained as controls. Trees in the adelgid and scale infestation treatments

104 were inoculated in the spring of 2014, 2015, 2016, and 2017 with infested foliage collected from

105 nearby adelgid-infested and scale-infested hemlocks, respectively; trees in the control treatment

106 had herbivore-free hemlock foliage placed on them to control for disturbance. 
In spring 2016, a gypsy moth outbreak occurred at our field site. Late-instar gypsy moth

108 larvae were regularly seen roaming on the ground, where they could crawl under the mesh bags

109 enclosing our trees. Over a short (2-3 week) time period, we observed that many of our trees

110 received substantial damage from gypsy moth larvae. In late June 2016, 69 trees in the adelgid-

111 infested treatment group, 69 trees in the scale-infested treatment group, and 107 trees in the

112 control treatment group were assessed for gypsy moth herbivory damage, for a total of 245 trees.

113 All branches emerging from the main stem of each tree were surveyed, and each tree was given a

114 combined damage score of $0-3(0=0-25 \%$ foliage loss, $1=26-50 \%, 2=51-75 \%, 3=76-100 \%)$. An

115 annual, early spring survey confirmed that trees did not experience foliage loss prior to the gypsy

116 moth outbreak. During the survey, gypsy moth larvae were confirmed to be the only folivores

117 present on trees.

118 Laboratory preference assay: Hemlock foliage used in the laboratory preference assay

119 came from 0.5-0.7m hemlock saplings purchased from Vans Pines Nursery (West Olive, MI) in

120 spring 2016. In late spring 2016, we inoculated half of the trees with adelgid-infested foliage

121 from nearby trees; we attached adelgid-free hemlock foliage to the other trees (the control group)

122 to control for disturbance. All trees were covered in mesh (Agribon-15, Johnny's Selected Seeds,

123 Waterville, ME, USA; 90\% light transmission) to prevent cross-contamination between

124 treatments and grown in 1-gallon pots outside of the greenhouse complex at the University of

125 Rhode Island (URI; Kingston, RI). Adelgid densities on each tree were assessed in late fall 2016

126 and early spring 2017. Five secondary branches on each tree were randomly selected, and all

127 adelgid present on the branches were counted. We used this data to ensure that both the trees and

128 specific branches used in this experiment had similar adelgid densities (0.8-1 adelgid/cm). 
In late spring 2017, we collected 40 gypsy moth larvae from a mixed-hardwood forest

130 located adjacent to the URI greenhouses. We collected $4^{\text {th }}-5^{\text {th }}$ instar larvae found wandering on

131 the ground or on tree trunks; all larvae were similarly-sized and highly active throughout the

132 experiment. To assess gypsy moth preference for adelgid-infested hemlock, we collected 40

$133 \sim 10 \mathrm{~cm}$ terminal branches: one branch from each of 20 adelgid-infested trees, and one branch

134 from each of 20 uninfested trees. Each branch was weighed; analysis via two-tailed Welch's

135 unequal variances t-test confirmed there was no significant difference in the mean branch weight

136 experienced by larvae in each treatment group $\left(\mathrm{t}_{36}=-0.72, \mathrm{P}=0.4731\right)$. Following weighing, the

137 branches were inserted into individual blocks of water-saturated floral foam (Oasis brand, Kent,

$138 \mathrm{OH}$ ). Two pieces of foliage (one adelgid-infested and one control) were then put in a $6 \mathrm{~L}$

139 polypropylene bin (Sterilite brand, Townsend, MA). The pieces of foliage were placed at the

$14025 \%$ and $75 \%$ marks between the left and right sides of the bin; treatment placement was

141 alternated between left and right. After two similarly-sized gypsy moth larvae were weighed,

142 they were both added to the center of each bin. Each bin was then covered with metal mesh held

143 in place by a rubber band. There were a total of 20 bins in the experiment. After one day, the

144 mesh was removed and the larvae and foliage (including any dropped needles) were weighed; the

145 adelgid-infested and uninfested foliage were weighed separately to calculate larval consumption

146 for each treatment.

147 Laboratory performance assay: Hemlock foliage used in the laboratory performance

148 assay came from the common garden planting described in the field preference survey. In late

149 spring 2018, $3^{\text {rd }}$-instar gypsy moth larvae were obtained from the USDA-APHIS Laboratory in

150 Buzzards Bay, MA. These larvae originated from the New Jersey Standard Strain-APHIS

151 substrain, a laboratory colony which has been in cultivation for $>60$ generations. Larvae were 
152 reared on an artificial diet (Frontier Agricultural Sciences, USDA Hamden Formula) until they

153 reached the fourth instar, at which point each larva was weighed and placed individually into one

154 of $50473 \mathrm{ml}$ glass mason jars (Ball brand, Broomfield CO). Fourth-instar larvae were used in

155 this experiment because younger stages have trouble consuming hemlock foliage, likely because

156 their undeveloped mouthparts cannot penetrate lignified needles. By contrast, larvae in the fourth

157 instar and above readily consume hemlock.

$158 \quad$ Half of the jars contained foliage from adelgid-infested hemlocks, while the other half of

159 the jars contained foliage from uninfested hemlocks, for a total of 25 replicates per treatment.

160 The foliage in each jar consisted of a single $\sim 17 \mathrm{~cm}$ sprig of foliage kept upright in hydrated

161 floral foam (Oasis brand, Kent, OH); foliage was checked every day and replaced if $>50 \%$ of the

162 needles had been consumed. The top of each jar was covered with nylon mesh and all jars were

163 kept in a growth chamber (15:9 L:D, $\left.24^{\circ} \mathrm{C}, 60-70 \% \mathrm{RH}\right)$. Larvae were checked every two days

164 and the position of the jars rotated within the growth chamber; the date of and weight at pupation

165 was recorded for each individual.

166 Statistical analysis: All data were inspected for normality (Shapiro-Wilk test) and

167 homoscedasticity (Bartlett's test) prior to analysis; data were log-transformed where necessary to

168 meet assumptions. Damage scores were tabulated by treatment group and analyzed via Pearson's

169 chi-squared test. Data from the laboratory preference assay were analyzed via two-tailed Welch's

170 unequal variances t-test. Percent weight gain, pupal weight and larval period were analyzed

171 separately via three-way analysis of covariance (ANCOVA), with foliage type and sex as the

172 predictors, initial larval weight as a covariate, and all two-way interactions. We classified larvae

173 as male or female because the sexes differ substantially in their time to and weight at pupation

174 (Myers et al., 1998); this allowed us to analyze percent weight gain, pupal weight, and larval 
175 period of the two sexes separately for both foliage treatment groups. Tukey's test was used to

176 separate the mean response of the two sexes in either foliage treatment group. Figures were

177 created using ggplot2 (Wickham, 2016). R software v. 3.5.0 was used for all statistical analyses

178 (R Development Core Team, 2018).

180 Results

181 Field preference survey: Adelgid-infested hemlocks experienced significantly more

182 gypsy moth herbivory damage than scale-infested or control trees $\left(X^{2}=48.96, \mathrm{P}<0.0001\right.$; Fig.

183 1). Nearly $40 \%$ of adelgid-infested trees lost more than half of their foliage to gypsy moth

184 herbivory, while fewer than $10 \%$ of scale-infested trees and $5 \%$ of control trees experienced

185 similar levels of damage. Conversely, $84 \%$ of both control and scale-infested trees experienced 186 minimal (0-25\% foliage loss) herbivory.

187 Laboratory preference assay: When allowed to choose between adelgid-infested and 188 control foliage, larvae consumed an average of $37 \%$ more adelgid-infested foliage than control 189 foliage $\left(0.36 \mathrm{~g}+/-0.054 \mathrm{SE}\right.$ and $0.22 \mathrm{~g}+/-0.034 \mathrm{SE}$, respectively; $\left.\mathrm{t}_{31}=-2.17, \mathrm{P}=0.0380\right)$.

190 Laboratory performance assay: Larvae reared to pupation on adelgid-infested hemlock

191 foliage gained more weight, and pupated at a higher weight, than larvae reared on uninfested

192 foliage (both P < 0.05; Fig. 2 A, B). Female larvae gained more weight, pupated at a higher

193 weight, and took longer to pupate than male larvae (all P < 0.05; Fig. 2 A, B, C). Initial larval

194 weight affected larval weight gain and weight at pupation, but not larval period.

195 Female larvae reared on adelgid-infested foliage gained $256 \%$ of their initial weight, 196 while those fed control foliage gained $120 \%$ of their initial weight $(\mathrm{P}<0.001$; Fig. 2 A). Male 
197 larvae reared on adelgid-infested and uninfested foliage gained $115 \%$ and $67 \%$ of their initial 198 weight, respectively (P < 0.001; Fig. 2 A).

199 Female larvae reared on adelgid-infested foliage pupated at weights $25 \%$ greater than 200 those reared on uninfested foliage $\left(\mathrm{F}_{1,36}=12.5, \mathrm{P}=0.0011\right.$; Fig. $\left.2 \mathrm{~B}\right)$. Conversely, male larvae 201 reared on adelgid-infested and control foliage pupated at similar weights $(\mathrm{P}=0.88$; Fig. 2 B $)$. 202 Larval period was not affected by treatment or initial weight (both $\mathrm{P}>0.4$; Fig. $2 \mathrm{C}$ ), 203 although female larvae reared on adelgid-infested hemlock foliage had a larval period five days 204 longer than that of male larvae reared on uninfested foliage ( $\mathrm{P}=0.0249$; Fig. $2 \mathrm{C})$.

206 Discussion

207 Here we present evidence that one destructive forest pest, hemlock woolly adelgid, 208 facilitates the development of the invasive gypsy moth. We found that gypsy moth larvae prefer 209 hemlock foliage infested with hemlock woolly adelgid (Fig. 1), and that feeding on this infested 210 foliage facilitates gypsy moth larval development. Female larvae reared on adelgid-infested

211 hemlock foliage gained more than twice as much of their initial weight (Fig. 2 A) and pupated at $21225 \%$ higher weights (Fig. 2 B) than larvae reared on uninfested foliage. Male larvae reared to 213 pupation on adelgid-infested foliage also gained $48 \%$ more weight than those fed uninfested 214 foliage (Fig. 2 A) but pupated similar weights (Fig. 2 B). Additionally, gypsy moth larvae 215 exhibited a preference for adelgid-infested foliage over uninfested foliage, and in a natural 216 setting, adelgid-infested hemlocks experienced substantially more gypsy moth herbivory than 217 uninfested trees. Our results are consistent with findings from previous studies documenting a 218 facilitative effect of hemlock woolly adelgid on other leaf-chewing herbivores. 
The enhanced performance of gypsy moth larvae reared on adelgid-infested foliage may

220 result from adelgid-induced changes to hemlock defenses. Adelgid infestation of hemlock

221 increases foliar emissions of methyl salicylic acid (Pezet et al., 2013; Pezet \& Elkinton, 2014)

222 and triggers salicylic acid (SA) accumulation in needles (Schaeffer et al., 2018; Rigsby et al.,

223 2019), activating SA-linked stress responses in hemlock. The accumulation of SA, and

224 subsequent monomerization of NPR1, has been shown to inhibit jasmonic acid (JA) biosynthesis

225 and JA-responsive gene expression (Zarate et al., 2007). Plant defense against leaf-chewing

226 herbivores is primarily mediated by JA (Gilbert \& Liebhold, 2010; Kroes et al., 2014), and

227 blocking the induction of JA-related defenses may make the foliage of adelgid-infested hemlocks

228 more digestible and/or easily converted into body mass by gypsy moth larvae. This interpretation

229 is supported by work on other systems where negative cross-talk between these pathways has

230 been shown to improve the performance of a later-arriving herbivore (reviewed in Stam et al.,

231 2014).

232

The improved performance of gypsy moth may also be driven by enhanced foliar

233 nutritional quality in adelgid-infested hemlocks. Hemlock needles on adelgid-infested stems are

234 higher in nitrogen, suggesting that hemlock woolly adelgid may turn needles into nitrogen-rich

235 sinks. For instance, amino acid content in adelgid-infested hemlock foliage has been measured at

236 levels 3.3-fold greater than uninfested foliage (Gomez et al., 2012). Nitrogen plays a key role in

237 the development and fecundity of herbivorous insects (Awmack \& Leather, 2002; Kerslake et

238 al., 1998). High concentrations of dietary nitrogen have been shown to increase gypsy moth

239 larval survival and pupal weights (Lindroth et al., 1997), and gypsy moth fecundity has been

240 positively correlated with host plant foliar nitrogen content (Hough \& Pimentel, 1978). This is

241 consistent with prior work in this system by Wilson et al. (2016) that found hemlock looper 
242 larvae reared on adelgid-infested foliage had higher early-instar survival and attained higher

243 pupal weights than larvae reared on uninfested foliage.

244 Adelgid-infested hemlocks in our common garden planting experienced significantly

245 higher rates of defoliation compared to both control (herbivore-free) and scale-infested trees

246 (Fig. 1). Laboratory choice-assays confirmed that gypsy moth larvae preferentially feed on

247 adelgid-infested hemlock foliage. In addition to documenting increased overall nitrogen and

248 amino acid concentrations in adelgid-infested hemlocks, Gomez et al. (2012) reported substantial

249 increases in levels of the amino acid proline. Proline can act as an indicator of plant stress

250 (Mattson \& Haack, 1987), and is an important source of stored energy for insects (Gäde \&

251 Auerswald, 2002). In this case, elevated proline content in adelgid-infested hemlocks may act as

252 a phagostimulatory signal of vulnerability and elevated nutrient content. This pattern has been

253 documented in other plant-insect systems, particularly for various Hemiptera, Lepidoptera,

254 Orthoptera and mite species (Mattson \& Haack, 1987).

255 The fact that adelgid feeding enhances gypsy moth preference for, and performance on,

256 eastern hemlock, makes it likely that their co-occurrence on hemlock can additively stress and

257 further threaten this important conifer. In southern New England, adelgid infestation has caused

258 extensive mortality of overstory hemlocks (Eschtruth et al., 2006; Orwig et al., 2002; Preisser et

$259 a l ., 2008)$, altering understory conditions that put hemlock seedlings at a competitive

260 disadvantage (Orwig et al., 2013; Orwig et al., 2008). Hemlocks are adapted to cool

261 microclimates and low light levels (Hadley, 2000), and increased light exposure due to crown

262 thinning and mortality of mature trees inhibits recruitment of hemlock seedlings and favors

263 establishment of black birch (Betula lenta) and other deciduous trees (Ingwell et al., 2012; Orwig

264 \& Foster, 1998; Orwig et al., 2002). Preferential feeding by gypsy moth larvae on adelgid- 
265 infested overstory hemlocks may exacerbate this effect, reducing the likelihood of new hemlock

266 recruits eventually repopulating devastated hemlock forests. The damage inflicted by gypsy

267 moths on adelgid-infested hemlock saplings may further compromise regeneration. Over a four-

268 year period, hemlock regeneration in adelgid-infested forests declined by $46 \%$ (Preisser et al.,

269 2011). Feeding by both species may accelerate this decline, if inhibited seedling recruitment is

270 coupled with significant mortality of juvenile hemlock saplings.

271 Enhanced performance of gypsy moth larvae on adelgid-infested hemlock may also have

272 a cascading effect on other plant taxa that grow with hemlock in forests of the eastern U.S. Oaks

273 (Quercus spp.) are a preferred host of gypsy moth (Barbosa et al., 1979; Hough \& Pimentel,

274 1978), and feeding by gypsy moth larvae has caused extensive mortality and decline of overstory

275 oaks throughout this region (Gandhi \& Herms, 2010). Total basal area of overstory oaks has

276 decreased due to gypsy moth herbivory, and mortality of white oak (Quercus alba), northern red

277 oak (Quercus rubra), and chestnut oak (Quercus montana) specifically has increased by $40 \%$

278 (Fajvan \& Wood, 1976). Gypsy moth herbivory in southern New England forests has increased

279 oak mortality and reduced the growth of surviving canopy trees by as much as $65 \%$ (Gottschalk

280 et al., 1990). It is plausible that the enhanced growth of female gypsy moth larvae on adelgid-

281 infested hemlock may translate to greater fecundity, which could increase gypsy moth population

282 densities in southern New England forests. Since tree mortality increases as the intensity and

283 frequency of gypsy moth defoliation increases (Davidson et al., 1999), larger gypsy moth

284 populations here could speed oak decline.

285 It is important to realize that ecological traits of the gypsy moth larvae used in the

286 laboratory performance assay may not be comparable with those of wild gypsy moth larvae.

287 Larvae used in the laboratory performance assay were part of the New Jersey Standard Strain- 
APHIS substrain, a mass-reared colony of gypsy moth larvae that has been in cultivation for $>60$ generations. Because this colony is intended for research, certain selective regimes and control

290 measures have been enacted upon it to maximize the survival and fecundity of the gypsy moths.

291 These include laboratory selection for higher survival and fecundity, and an artificial diet

292 (Frontier Agricultural Sciences, USDA Hamden Formula), which may incidentally select for

293 genotypes that show reduced performance on a natural diet (Grayson et al., 2015). However, a

294 comparison of development between gypsy moth larvae from the New Jersey Standard Strain-

295 APHIS substrain, -FS substrain, and three wild populations all reared on a natural diet, found no

296 population-level differences in male and female pupal weights (Grayson et al., 2015).

297 Additionally, our observation of substantial wild gypsy moth larval herbivory damage to adelgid-

298 infested field-grown eastern hemlocks, as well as a confirmed wild gypsy moth larval preference

299 for adelgid-infested hemlocks, mirror results from the laboratory performance assay and further 300 support their ecological relevance.

$301 \quad$ Adelgid-induced hemlock mortality has severely affected ecosystem dynamics in eastern

302 U.S. forests. Hemlock supports critical habitat for unique vertebrate and invertebrate

303 communities (Ellison et al., 2010), and dramatic shifts in understory vegetation, soil nutrient

304 cycling and hydrological regimes may have long-lasting changes that compromise these areas

305 (Orwig et al., 2008). Future work should evaluate the extent to which adelgid and gypsy moth 306 act synergistically to speed the decline of eastern hemlock and other canopy-dominant species, 307 and the impact this could have on hemlock-associated ecosystems. 308 309 Acknowledgments 
We thank Elizabeth Tewksbury for providing the larval growth chamber, USDA APHIS

311 for providing gypsy moth larvae, Catherine Conroy for assistance with rearing larvae, and two

312 anonymous reviewers for comments that substantially improved the manuscript. This research

313 was supported by PA Department of Conservation and Natural Resources DCNR 2016-001-

314 HWA-URI, DCNR 2018-001-HWA-URI, COLCOM Foundation \#20015270, and USDA

315 McIntire-Stennis RI0017-MS979.

316 The authors have no conflicts of interest to declare.

317 There are no disputes over the ownership of the data presented in this paper. All

318 contributions have been attributed appropriately, via coauthorship or acknowledgement, as

319 appropriate to the situation.

320

321 Contribution of Authors

322 IGK, ELP, CMR, and CMO were responsible for project design. IGK, AKB, ERW, SKS, EES, 323 and ELP were responsible for data collection and analysis. IGK, ELP, AKB, CMR, and CMO 324 were responsible for paper writing.

325

326 References

327 Abella, S.R. (2018) Forest decline after a 15-year "perfect storm” of invasion by hemlock woolly 328 adelgid, drought, and hurricanes. Biological Invasions, 20, 695-707.

329 Awmack, C.S. \& Leather, S.R. (2002) Host plant quality and fecundity in herbivorous insects.

$330 \quad$ Annual Review of Entomology, 47, 817-844. 
331 Barbosa, P., Greenblatt, J., Withers, W., Cranshaw, W. \& Harrington, E.A. (1979) Host-plant

332 preferences and their induction in larvae of the gypsy moth, Lymantria dispar. Entomologia

333 Experimentalis et Applicata, 26, 180-188.

334 Davidson, C.B., Gottschalk, K.W. \& Johnson, J.E. (1999) Tree mortality following defoliation

335 by the European gypsy moth (Lymantria dispar L.) in the United States: A review. Forest

$336 \quad$ Science, $\mathbf{4 5}, \mathbf{7 4 - 8 4 .}$

337 Dharmadi, S.N., Elliott, K.J. \& Miniat, C.F. (2019) Lack of forest tree seedling recruitment and

338 enhanced tree and shrub growth characterizes post-Tsuga canadensis mortality forests in the

339 southern Appalachians. Forest Ecology and Management, 440, 122-130.

340 Domec, J.C., Rivera, L.N., King, J.S., Peszlen, I., Hain, F., Smith, B. \& Frampton, J. (2013)

341 Hemlock woolly adelgid (Adelges tsugae) infestation affects water and carbon relations of

342 eastern hemlock (Tsuga canadensis) and carolina hemlock (Tsuga caroliniana). New

343 Phytologist, 199, 452-463.

344 Ellison, A.M., Barker-Plotkin, A.A., Foster, D.R. \& Orwig, D.A. (2010) Experimentally testing

345 the role of foundation species in forests: the Harvard Forest Hemlock Removal Experiment.

$346 \quad$ Methods in Ecology and Evolution, 1, 168-179.

347 Eschtruth, A.K., Cleavitt, N.L., Battles, J.J., Evans, R.A. \& Fahey, T.J. (2006) Vegetation

348 dynamics in declining eastern hemlock stands: 9 years of forest response to hemlock woolly

349 adelgid infestation. Canadian Journal of Forest Research, 36, 1435-1450.

350 Fajvan, M.A. \& Wood, J.M. (1996) Stand structure and development after gypsy moth

351 defoliation in the Appalachian plateau. Forest Ecology and Management, 89, 79-88. 
352 Gäde, G. \& Auerswald, L. (2002) Beetles' choice — proline for energy output: control by AKHs. 353 Comparative Biochemistry and Physiology Part B: Biochemistry and Molecular Biology, 132, $354 \quad 117-129$.

355 Gandhi, K.J.K. \& Herms, D.A. (2010) Direct and indirect effects of alien insect herbivores on 356 ecological processes and interactions in forests of eastern North America. Biological 357 Invasions, 12, 389-405.

358 Gilbert, M. \& Liebhold, A. (2010) Comparing methods for measuring the rate of spread of 359 invading populations. Ecography, 33, 809-817.

360 Gomez, S., Orians, C.M. \& Preisser, E.L. (2012) Exotic herbivores on a shared native host: 361 tissue quality after individual, simultaneous, and sequential attack. Oecologia, 169, 10153621024.

363 Gonda-King, L., Gómez, S., Martin, J.L., Orians, C.M. \& Preisser, E.L. (2014) Tree responses to 364 an invasive sap-feeding insect. Plant Ecology, 215, 297-304.

365 Gonda-King, L., Radville, L. \& Preisser, E.L. (2012) False ring formation in eastern hemlock 366 branches: impacts of hemlock woolly adelgid and elongate hemlock scale. Environmental 367 Entomology, 41, 523-531.

368 Gottschalk, K.W., Twery, M.J. \& Smith, S.I., (1990) Proceedings, U.S. Department of 369 Agriculture interagency gypsy moth research review. Gen. Tech. Rep, 146, 27-39.

370 Grayson, K.L., Parry, D., Faske, T.M., Hamilton, A., Tobin, P.C., Agosta, S.J. \& Johnson, D.M. 371 (2015) Performance of wild and laboratory-reared gypsy moth (Lepidoptera: Erebidae): A 372 comparison between foliage and artificial diet. Environmental Entomology, 44, 864-873.

373 Hadley, J.L. (2000) Understory microclimate and photosynthetic response of saplings in an old374 growth eastern hemlock (Tsuga canadensis L.) forest. Ecoscience, 7, 66-72. 
375 Hough, J.A. \& Pimentel, D. (1978) Influence of host foliage on development, survival, and 376 fecundity of the gypsy moth. Environmental Entomology, 7, 97-102.

377 Ingwell, L.L., Miller-Pierce, M., Trotter, R.T., III \& Preisser, E.L. (2012) Vegetation and 378 invertebrate community response to eastern hemlock decline in southern New England. $379 \quad$ Northeastern Naturalist, 19, 541-558.

380 Kaplan, I. \& Denno, R.F. (2007) Interspecific interactions in phytophagous insects revisited: a 381 quantitative assessment of competition theory. Ecology Letters, 10, 977-994.

382 Kerslake, J., Woodin, S. \& Hartley, S. (1998) Effects of carbon dioxide and nitrogen enrichment 383 on a plant-insect interaction: the quality of Calluna vulgaris as a host for Operophtera 384 brumata. New Phytologist, 140, 43-53.

385 Kroes, A., van Loon, J.J. \& Dicke, M. (2014) Density-dependent interference of aphids with 386 caterpillar-induced defenses in Arabidopsis: involvement of phytohormones and transcription 387 factors. Plant and Cell Physiology, 56, 98-106.

388 Li, Y., Dicke, M., Harvey, J.A. \& Gols, R. (2014) Intra-specific variation in wild Brassica $389 \quad$ oleracea for aphid-induced plant responses and consequences for caterpillar-parasitoid 390 interactions. Oecologia, 174, 853-862.

391 Lindroth, R.L., Klein, K.A., Hemming, J.D. \& Feuker, A.M. (1997) Variation in temperature and 392 dietary nitrogen affect performance of the gypsy moth (Lymantria dispar L.). Physiological 393 Entomology, 22, 55-64.

394 Lovett, G.M., Canham, C.D., Arthur, M.A., Weathers, K.C. \& Fitzhugh, R.D. (2006) Forest 395 ecosystem responses to exotic pests and pathogens in eastern North America. BioScience, 56, $396 \quad 395-405$. 
Mattson, W.J. \& Haack, R.A. (1987) The role of drought in outbreaks of plant-eating insects.

$398 \quad$ BioScience, 37, 110-118.

399 McClure, M.S. (1991) Density-dependent feedback and population cycles in Adelges tsugae

400 (Homoptera: Adelgidae) on Tsuga canadensis. Environmental Entomology, 20, 258-264.

401 Myers, J. H., Boettner, G.H. \& Elkinton, J.S. (1998) Maternal effects in gypsy moth: only sex

402 ratio varies with population density. Ecology, 79, 305-314.

403 Nykänen, H. \& Koricheva, J. (2004) Damage-induced changes in woody plants and their effects

404 on insect herbivore performance: a meta-analysis. Oikos, 104, 247-268.

405 Ohgushi, T. (2008) Herbivore-induced indirect interaction webs on terrestrial plants: the

406 importance of non-trophic, indirect, and facilitative interactions. Entomologia Experimentalis

407 et Applicata, 128, 217-229.

408 Orwig, D.A., Barker Plotkin, A.A., Davidson, E.A., Lux, H., Savage, K.E. \& Ellison, A.M.

409 (2013) Foundation species loss affects vegetation structure more than ecosystem function in a 410 northeastern USA forest. PeerJ, 1, e41.

411 Orwig, D.A., Cobb, R.C., D’Amato, A.W., Kizlinski, M.L. \& Foster, D.R. (2008) Multi-year

412 ecosystem response to hemlock woolly adelgid infestation in southern New England forests.

413 Canadian Journal of Forest Research, 38, 834-843.

414 Orwig, D.A. \& Foster, D.R. (1998) Forest response to the introduced hemlock woolly adelgid in 415 southern New England, USA. Journal of the Torrey Botanical Society, 125, 60-73.

416 Orwig, D.A., Foster, D.R. \& Mausel, D.L. (2002) Landscape patterns of hemlock decline in New 417 England due to the introduced hemlock woolly adelgid. Journal of Biogeography, 29, 1475$418 \quad 1487$. 
419 Pezet, J., Elkinton, J., Gomez, S., McKenzie, E.A., Lavine, M. \& Preisser, E.L. (2013) Hemlock

420 woolly adelgid and elongate hemlock scale induce changes in foliar and twig volatiles of

421 eastern hemlock. Journal of Chemical Ecology, 39, 1090-1000.

422 Pezet, J. \& Elkinton, J.S. (2014) Hemlock woolly adelgid (Hemiptera: Adelgidae) induces twig 423 volatiles of eastern hemlock in a forest setting. Environmental Entomology, 43, 1275-1285.

424 Preisser, E.L., Lodge, A.G., Orwig, D.A. \& Elkinton, J.S. (2008) Range expansion and

425 population dynamics of co-occurring invasive herbivores. Biological Invasions, 10, 201-213.

426 Preisser, E.L., Miller-Pierce, M.R., Vansant, J. \& Orwig, D.A. (2011) Eastern hemlock (Tsuga

427 canadensis) regeneration in the presence of hemlock woolly adelgid (Adelges tsugae) and

428 elongate hemlock scale (Fiorinia externa). Canadian Journal of Forest Research, 41, 2433-

$429 \quad 2439$.

430 Rigsby, C.M., Shoemaker, E.E., Mallinger, M.M., Orians, C.M. \& Preisser, E.L. (2019) Conifer

431 responses to a stylet-feeding invasive herbivore and induction with methyl jasmonate: impact

432 on the expression of induced defences and a native folivore. Agricultural and Forest

$433 \quad$ Entomology, 21, 227-234.

434 Schaeffer, R.N., Wang, Z., Thornber, C.S., Preisser, E.L. \& Orians, C.M. (2018) Two invasive

435 herbivores on a shared host: patterns and consequences of phytohormone induction.

436 Oecologia, 186, 973-982.

437 Shields, K.S., Young, R.F. \& Berlyn, G.P. (1995) Hemlock woolly adelgid (Homoptera:

438 Adelgidae): stylet bundle insertion and feeding sites. Annals of the Entomological Society of $439 \quad$ America, 88, 827-835.

440 Simberloff, D. \& Von Holle, B. (1999) Positive interactions of nonindigenous species: invasional 441 meltdown? Biological Invasions, 1, 21-32. 
442 Stam, J. M., Kroes, A., Li, Y., Gols, R., van Loon, J. J., Poelman, E. H. \& Dicke, M. (2014)

443 Plant interactions with multiple insect herbivores: from community to genes. Annual Review 444 of Plant Biology, 65, 689-713.

445 Walling, L.L. (2000) The myriad plant responses to herbivores. Journal of Plant Growth 446 Regulation, 19, 195-216.

447 Walling, L.L. (2008) Avoiding effective defenses: strategies employed by phloem-feeding $448 \quad$ insects. Plant Physiology, 146, 859-866.

449 Wickham, H. (2016) ggplot2: Elegant Graphics for Data Analysis. Springer-Verlag New York.

450 Wilson, C.M., Schaeffer, R.N., Hickin, M.L., Rigsby, C.M., Sommi, A.F., Thornber, C.S., 451 Orians, C.M. \& Preisser, E.L. (2018) Chronic impacts of invasive herbivores on a 452 foundational forest species: a whole-tree perspective. Ecology, 99, 1783-1791.

453 Wilson, C.M., Vendettuoli, J.F., Orwig, D.A. \& Preisser, E.L. (2016) Impact of an invasive 454 insect and plant defense on a native forest defoliator. Insects, 7, 513-519.

455 Zarate, S.I., Kempema, L.A. \& Walling, L.L. (2007) Silverleaf whitefly induces salicylic acid 456 defenses and suppresses effectual jasmonic acid defenses. Plant Physiology, 143, 866-875. 


\section{Figure Legends}

Figure 1. Gypsy moth larval herbivory damage to eastern hemlocks in adelgid (Adelges

460 tsugae)-infested, uninfested control, and scale (Fiorinia externa)-infested treatment groups.

461 Damage was quantified on a scale of 0-3, representing $\%$ foliage loss of trees in each treatment

462 group $(0=0-25 \%$ foliage loss, $1=26-50 \%, 2=51-75 \%, 3=76-100 \%)$.

Figure 2. Percent weight gain (A), pupal weight (B), and larval period (C) of gypsy moth

464 larvae reared on either adelgid-infested or uninfested control hemlock foliage. Bars represent

465 means +/- $1 \mathrm{SE} ; \mathrm{F}=$ female larvae, $\mathrm{M}=$ male larvae. Capital letters denote significant treatment-

466 level differences $(\mathrm{P}<0.05)$. 
Figure 1.

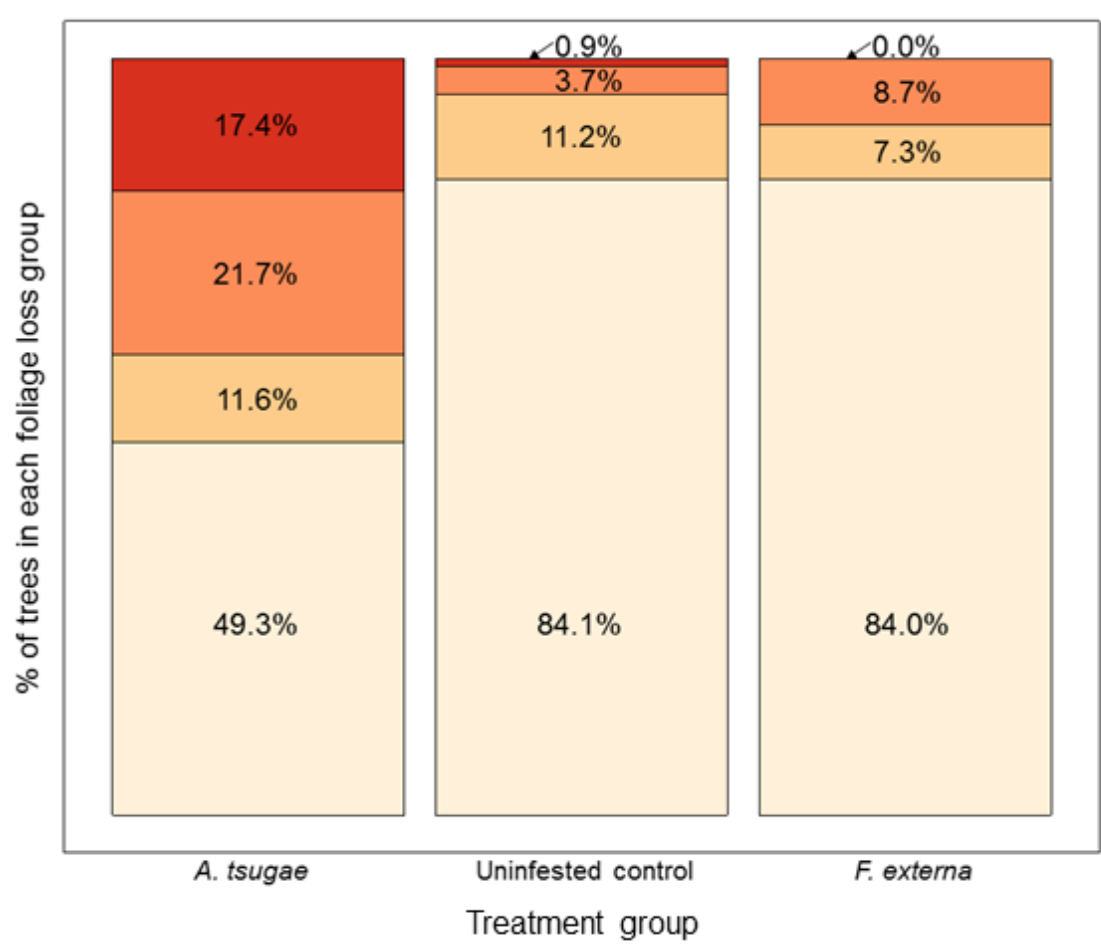

Foliage loss group

$76-100 \%$

$51-75 \%$

26- $50 \%$

$0-25 \%$ 
Figure 2.
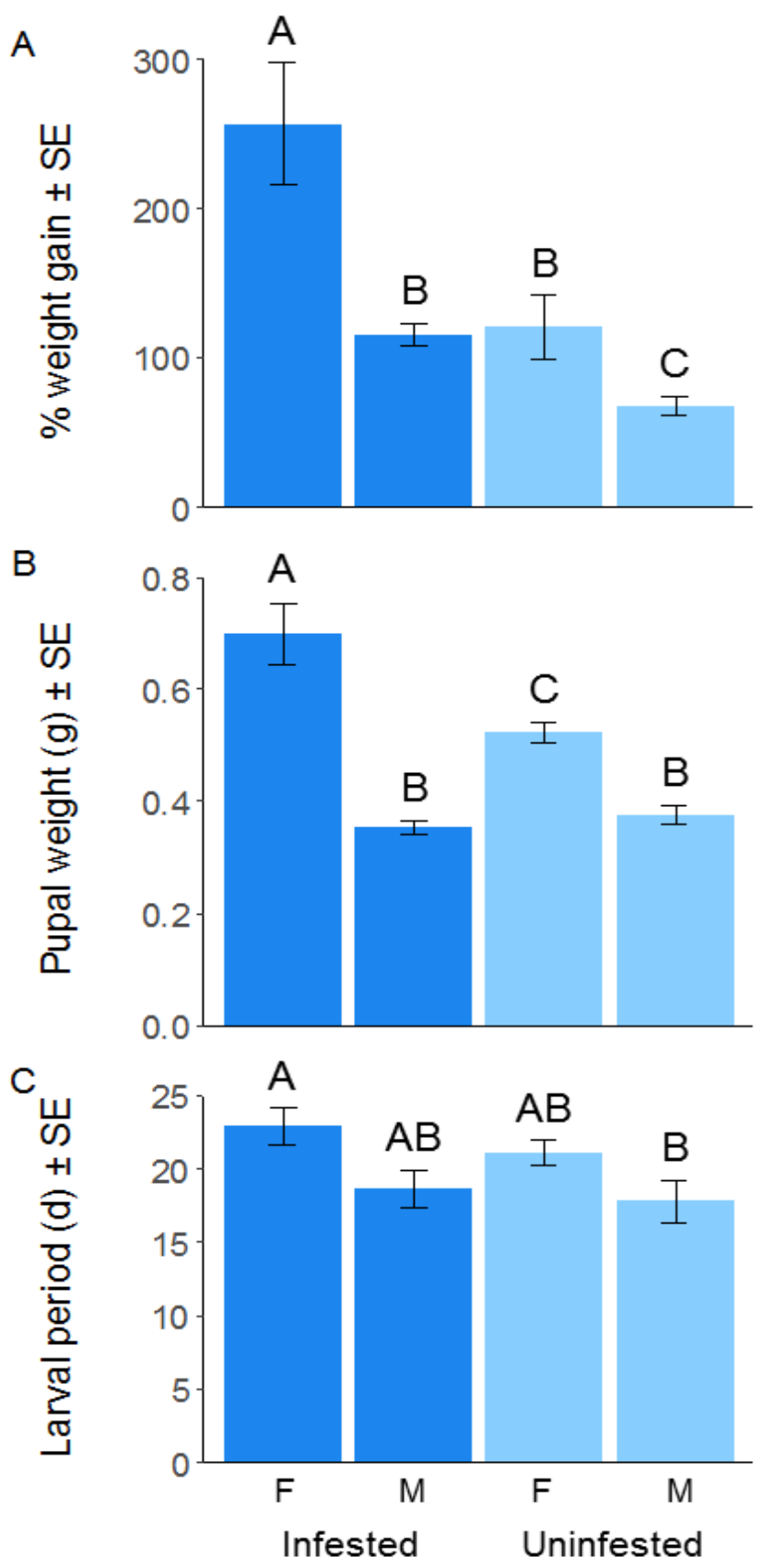

Foliage treatment 